\author{
Atif Bilal ASLAM \\ Houshmand E. MASOUMI \\ Nida NAEEM \\ Mohammad AHMAD
}

\title{
Residential location choices and the role of mobility, socioeconomics, and land use in Hafizabad, Pakistan
}

Residential self-selection in developing countries and its relation to urban transportation are understudied and not fully understood. This knowledge gap is even greater in the case of small cities in the developing world. This study takes Hafizabad, Pakistan as a case study with the objective of providing data for future quantitative analyses about residential location choices in small cities on the Indian subcontinent. A sample of 365 residents was interviewed from four neighbourhoods with a combined population of 19,042 . This resulted in individual and household response rates of $1.92 \%$ and $12.65 \%$ and confidence levels of $\pm 5.08 \%$ and $\pm 4.79 \%$ for individual and household questions. The results show that the most important factors influencing residents' decisions about moving are availability of utilities/services and afforda- ble prices. Factors related to transportation, accessibility, and social issues, such as proximity to work and relatives, come next. The role of transportation in residential location choices in Hafizabad is less important in comparison to high-income countries. This finding shows how urban form can shape residents' travel behaviour and suggests that small cities are more compact and walkable because about $40 \%$ of job-related trips are made by walking. The results of this study will help inform relevant government organizations about how to effectively devise policies for small cities because policies grafted from large metropolises might not work well at a smaller scale.

Keywords: residential self-selection, urban transportation, human perceptions, Pakistan 


\section{Introduction}

Over the past two decades, residential location choices have increasingly attracted the attention of urban transport researchers studying urban travel behaviour and land-use interactions. Scholars are interested in whether people choose to live in a neighbourhood where they can easily commute or access their non-work destinations or whether they choose where to live due to other factors such as mobility needs, the effects of the built environment, their perceptions and lifestyles, and socioeconomics.

According to the figures released by the Government of Pakistan (2017), the population of Pakistan has increased to 207.8 million from 132.4 million in 1998 (a 57\% increase), showing an annual average growth rate of 2.40 during the inter-census period (1998-2017). Although there was a decline in annual growth from the previous inter-census period (1981-1998), the urban share of the population has increased to $36.38 \%$ (2017) from $32.52 \%$ (1998). This shows a growing phenomenon of urbanization and a trend of population concentration in urban centres. The existing urban housing stock is under growing pressure due to this, which has resulted in urban sprawl. Uncontrolled urbanization is becoming a major challenge for local planning agencies in Pakistan (Ahmad \& Anjum, 2012). A number of development plans have been prepared by local planning agencies to control the situation; however, they have failed to meet their objectives. Hameed and Nadeem (2008) critically reviewed the urban master planning processes in Pakistan and found several reasons for unsuccessful implementation of these plans. One of the many reasons for failure in plan implementation was greater reliance on secondary data, minimum primary data collection, and inadequate public participation. Given this, many of the master plan proposals related to the housing sector (e.g., identifying future residential growth areas) do not meet people's aspirations and needs, thus hampering successful implementation.

Other than basic quantitative housing indicators, housing census data in Pakistan do not provide any insight into people's choices and preferences when choosing where to live. Further, there are not enough data for studying the role of transportation and other related factors in residential location choices in Pakistan (and other countries of the Global South). Many past studies on this topic have found a significant relationship between the built environment and urban travel behaviour. However, less well understood is the effect of residential self-selection on the relation between land use and transportation (Cao et al., 2009). Primary data become more necessary when one sees how rare findings for Pakistan and the developing world are. This situation provides a rationale to collect primary data on this topic in the developing world.

As a result, this study was conducted with the objective of providing reliable primary data to carry out empirical analyses on residential self-selection in small Pakistani cities. It is based on the overall hypothesis of this study: that the perceptions and behaviours of people in a "small city" in Pakistan will not be comparable to cities with a similar size in North America, Europe, Australia, and so on. In other words, the decisive cause of the behavioural difference is the context, not the size. However, inside the Pakistani or South Asian context, city size may be the reasons for behavioural mismatches. Because of differences in socioeconomics and lifestyles in large and medium-sized cities compared to small cities, these mismatches might be large. These behavioural disparities between different city sizes can be larger in the developing world compared to high-income countries (this needs to be tested and can serve as a hypothesis for other studies). This study addresses the lack of appropriate primary data suitable for investigating location choices, not only in small Pakistani cities, but also in cities of other sizes.

The first section of this article features an introduction, a problem statement, and study objectives. The next section reviews past studies conducted on related topics in various contexts, mainly in developed countries and countries of the Middle East and North Africa and the Indian subcontinent. The next section outlines the research methodology by presenting the research questions and hypothesis, case-study area profile, study variables, and data collection and analysis methods. Findings derived from the collected data in two broad sets of categorical and continuous variables are presented in the following section. The last two sections provide topic-specific discussion and the conclusions of the study.

\section{Previous studies}

Residential location choices are a part of self-selections, which are people's tendencies to make decisions about where to live, travel, life, and so on based on their needs, preferences, and attitudes. This has been the topic of empirical studies based on primary data collected in several countries, including the Netherlands (Van der Vlist et al., 2002; Zondag \& Pieters, 2005; Ettema \& Nieuwenhuis, 2017), Germany (Heldt et al., 2016), the UK (Kim et al., 2005), the United States (Schwanen \& Mokhtarian, 2004; Bayoh et al., 2006; Waddell et al., 2007; Cao et al., 2010; Pinjari et al., 2011; Sener et al., 2011; Wang et al., 2011; Patacchini \& Arduini, 2016), Canada (Fatmi et al., 2017), Japan (Ge \& Hokao, 2006; Zhang et al., 2014; Yu et al., 2017), Ireland (Vega \& Reynolds-Feighan, 2009; 
Humphreys \& Ahern, 2017), Italy (Chiarazzo et al., 2014), France (Palma et al., 2005; Buczkowska \& Lapparent, 2014), Denmark (Næss, 2009), and Belgium (van Acker et al., 2014; Vos \& Witlox, 2016). These studies range from literature reviews (Van der Vlist et al., 2002) to numerical analysis using national (Zondag \& Pieters, 2005) and city- or regional-level census databases (Wang et al., 2011; Vega \& Reynolds-Feighan, 2009; Pinjari et al., 2011; Sener et al., 2011; Buczkowska \& Lapparent, 2014; Heldt et al., 2016) and mathematical modelling using primary data (Schwanen \& Mokhtarian, 2004; Kim et al., 2005; Bayoh et al., 2006; Ge \& Hokao, 2006; Næss, 2009; Chiarazzo et al., 2014; van Acker et al., 2014; Zhang et al., 2014; Patacchini \& Arduini, 2016; Vos \& Witlox, 2016; Fatmi et al., 2017; Humphreys \& Ahern, 2017; Yu et al., 2017), as well as statistical analysis of data produced by simulators (Palma et al., 2005). Most studies were conducted with mathematical modelling using primary data. Geographically, most of the case-study areas have been located in the United
States. Some studies have also been conducted on the topic in emerging and developing countries, such as China (Biying et al., 2012; Næss, 2013; Wu et al., 2013; Yang et al., 2013; Wang et al., 2016, 2018; Zhuge et al., 2016), Korea (Jun et al., 2013; Yi \& Lee, 2014; Park \& Kim, 2016), Thailand (Choocharukul et al., 2008), Vietnam (Tran et al., 2016), Chile (Balbontin et al., 2015), and Israel (Frenkel et al., 2013).

The share of residential location choice studies for the Indian subcontinent, the Middle East, and North Africa is small. Apart from some notable exceptions, such as studies carried out in India (Schwanen \& Mokhtarian, 2003; Molugaram \& Rao, 2005; Srinivasan, 2005; Lall et al., 2006), Bangladesh (Choudhury \& Ayaz, 2015), Iran (Masoumi, 2013), and Egypt (Ibrahim, 2017), a limited number of studies have been undertaken to present a better picture of self-selections in the countries of these vast regions. Studies related to Pakistan are almost non-existent in this literature. Given more frequent in-

Table 1: Methodological considerations of similar past studies (source: authors).

\begin{tabular}{|c|c|c|c|c|c|}
\hline Study & Sample size & $\begin{array}{l}\text { Response } \\
\text { rate }\end{array}$ & Case-study areas & $\begin{array}{l}\text { Response } \\
\text { ratio }\end{array}$ & $\begin{array}{l}\text { Data collection } \\
\text { method }\end{array}$ \\
\hline Ahmad, 1992 & $\begin{array}{l}6,275 \text { households selected } \\
\text { through quasi-random sam- } \\
\text { pling }\end{array}$ & - & $\begin{array}{l}\text { Twenty-six zones of Karachi } \\
\text { based on socioeconomic and } \\
\text { neighbourhood characteristics }\end{array}$ & Not available & $\begin{array}{l}\text { City-wide socio- } \\
\text { economic survey } \\
\text { in 1987-1988 }\end{array}$ \\
\hline Ahmad, 1993 & $\begin{array}{l}6,275 \text { households selected } \\
\text { through quasi-random sam- } \\
\text { pling }\end{array}$ & - & $\begin{array}{l}\text { Twenty-six zones of Karachi } \\
\text { based on socioeconomic and } \\
\text { neighbourhood characteristics }\end{array}$ & $0.38 \%$ (city) & $\begin{array}{l}\text { City-wide socio- } \\
\text { economic survey } \\
\text { in 1987-1988 }\end{array}$ \\
\hline Cao et al., 2006a & $\begin{array}{l}6,000 \text { randomly selected } \\
\text { households }\end{array}$ & $22.8 \%(1,368)$ & $\begin{array}{l}\text { Six middle-income neighbour- } \\
\text { hoods belonging to three } \\
\text { different periods in Austin, TX }\end{array}$ & $4.64 \%$ & $\begin{array}{l}\text { Self-administered } \\
\text { mailed survey } \\
\text { in } 1995\end{array}$ \\
\hline Cao et al., $2006 \mathrm{~b}$ & $\begin{array}{l}8,000(6,746 \text { valid) households } \\
\text { randomly selected from a com- } \\
\text { mercially maintained database }\end{array}$ & $24.9 \%(1,682)$ & $\begin{array}{l}\text { Eight neighbourhoods of } \\
\text { varying characteristics belong- } \\
\text { ing to two different periods in } \\
\text { northern California }\end{array}$ & $1.74 \%$ & $\begin{array}{l}\text { Two rounds of } \\
\text { self-administered } \\
\text { mailed survey } \\
\text { in } 2003\end{array}$ \\
\hline Frank et al., 2007 & $\begin{array}{l}\text { Two sub-samples: } 2,088 \text { (2,056 } \\
\text { valid) and 1,466 (1,455 valid) } \\
\text { households selected from the } \\
\text { SMARTRAQ study }\end{array}$ & $30.4 \%$ & $\begin{array}{l}\text { The thirteen-county Atlanta } \\
\text { region }\end{array}$ & Not available & $\begin{array}{l}\text { Computer-aided } \\
\text { telephone interview } \\
\text { in } 2001 \text { and } 2002\end{array}$ \\
\hline $\begin{array}{l}\text { Handy \& Clifton, } \\
2001\end{array}$ & $\begin{array}{l}6,000 \text { respondents and } 75 \\
\text { interview participants }\end{array}$ & $22.8 \%(1,368)$ & $\begin{array}{l}\text { Six middle-income neighbour- } \\
\text { hoods belonging to three } \\
\text { different periods in Austin, TX }\end{array}$ & $4.64 \%$ & $\begin{array}{l}\text { Self-administered } \\
\text { mailed survey } \\
\text { in } 1995 \text { and a focus } \\
\text { group in } 1997\end{array}$ \\
\hline Ibrahim, 2017 & 224 households & - & $\begin{array}{l}\text { Seven residential districts of } \\
\text { Alexandria }\end{array}$ & $0.01 \%$ (city) & Field survey \\
\hline $\begin{array}{l}\text { Kitamura et al., } \\
1997\end{array}$ & $\begin{array}{l}5,472 \text { randomly selected } \\
\text { households }\end{array}$ & $17.6 \%(963)$ & $\begin{array}{l}\text { Five study sites, each compris- } \\
\text { ing approximately a square } \\
\text { mile in the San Francisco Bay } \\
\text { area }\end{array}$ & Not available & $\begin{array}{l}\text { Self-administered } \\
\text { mailed survey }\end{array}$ \\
\hline Painter, 1996 & $\begin{array}{l}496 \text { randomly selected } \\
\text { pedestrians }\end{array}$ & - & $\begin{array}{l}\text { Three similar streets and a } \\
\text { footpath in London }\end{array}$ & Not available & $\begin{array}{l}\text { On-street pedestrian } \\
\text { survey in } 1992\end{array}$ \\
\hline Mokhtarian, 2003 & 8,000 households & $\begin{array}{l}25.0 \% \text { (2000: } \\
1,358 \text { valid } \\
\text { workers) }\end{array}$ & $\begin{array}{l}\text { Three neighbourhoods in the } \\
\text { San Francisco Bay area }\end{array}$ & Not available & $\begin{array}{l}\text { Self-administered } \\
\text { mailed survey }\end{array}$ \\
\hline
\end{tabular}


vestigations of self-selections in India, rough generalization of findings can be made, but, due to some key differences (mainly related to religious beliefs), independent studies of the Pakistani context seem necessary. The findings of one of the rare studies on Pakistan were published in 1992 by Ahmad, who studied a sample of 6,275 households in Karachi using data from a city-wide socioeconomic survey conducted in 1987 and 1988. By analysing the data, she concluded that ethnicity is important in determining households' location choices and mobility. Ahmad also found relations between these considerations with urban sprawl and outward growth of Karachi. Another study was conducted by Connor (1989), who found that ethnographic ties, political involvement, and lack of political activity motivated residential association. These two Pakistani studies were conducted many years ago and had only a weak or no relation to urban travel behaviour.

A review of past studies shows that the topic has mainly been explored through quantitative methods with probabilistic sampling techniques as the main method for sampling and recruiting the respondents. Many such studies also used some samples already available - census data, previous studies, or any other maintained databases - to determine how large the sample size should be and to identify the target population. Neighbourhoods or residential districts remained the main unit of analysis for conducting many of these studies at different locations. The key considerations for the selection of these neighbourhoods were primarily similarities or differences in socioeconomic characteristics and the time period when these neighbourhoods were developed or inhabited. Two main data-collection approaches were employed: direct interviews through field surveys and self-administered mailed surveys. The limitation with the self-administered mailed survey is the low response rate, as is also evident from the review of such studies, because none of them could achieve a response rate of more than $33 \%$ (see Table 1). In turn, the response ratio (the sample coverage of the overall neighbourhood/city population in terms of percentage) ranged from a low of $1.74 \%$ to a high of $4.64 \%$. Table 1 summarizes the methodology of some past studies.

\section{Methodology}

This study assumes that residential self-selections are context-sensitive; that is, people in Pakistan choose where to live differently compared to other contexts. These differences are very much connected to cultural issues (religion, local lifestyles, and mentality), socioeconomics (exemplified by people's different approaches to earning money), social classes and the connection to space, and geography (such as climate). It is assumed that these phenomena can motivate different approach- es to residential location choices in small cities in the Pakistani context compared to the contexts in Western or high-income countries. This assumption is based on the hypothesis that the interrelations between urban space and urban travel behaviour (in this case, commuting to one's place of work or study) are highly context-specific, and so policymaking for urban mobility cannot be based on studies or concepts rooted in high-income countries, but must be based on local studies. This study presents data that provide a basis for in-depth analysis in future studies. The main question is how Pakistanis choose where to live in small cities.

\subsection{Case-study areas}

Life in large urban centres is a multitude of many complex processes, making it very difficult to create reliable findings out of empirical studies conducted in urban settings. Conducting such studies in large urban centres requires great investment of effort and resources to produce reliable conclusions. In comparison, smaller cities offer opportunities to reliably analyse less complex urban life through the established research frame. Accounting for many of the underlying factors is easier than in large urban centres. Given this fact, the small town of Hafizabad, located in the upper central Punjab region with a population of 245,784 (2017), was chosen to carry out this study (see Figure 1). According to the latest census (Government of Pakistan, 2017), Hafizabad has 37,270 housing units with an average household size of 6.6 persons - almost the same as the national average, at 6.5.

The large city nearest Hafizabad is Gujranwala (population 2.0 million in 2017), located $55 \mathrm{~km}$ to the east. Hafizabad has a strong link with Gujranwala and there is a commuting pattern between these two cities, although on a limited scale. The Hafizabad district is well known for its rice and cotton textile industries and, as the district capital, Hafizabad also offers job opportunities to its surrounding population, which commutes daily to the city centre (Naeem \& Ahmad, 2018). The other large cities near Hafizabad are Lahore (population 11.1 million in 2017), located $102 \mathrm{~km}$ to the southeast, and Faisalabad (population 3.2 million in 2017), located 106 $\mathrm{km}$ to the southwest and with which there are socioeconomic links.

Although the history of the region where Hafizabad is located reaches as far back as $327 \mathrm{BC}$, to Alexander the Great's invasion of Punjab (Government of the Punjab, 2018), Hafizabad itself was founded by the city's namesake, Hafiz Meerak, a companion of Mughal Emperor Akbar I (1542-1605). The older central part of the city thus has some visible features reflecting an urban layer of Mughal architecture dating back to the sixteenth century. After the fall of the Mughal Empire, 

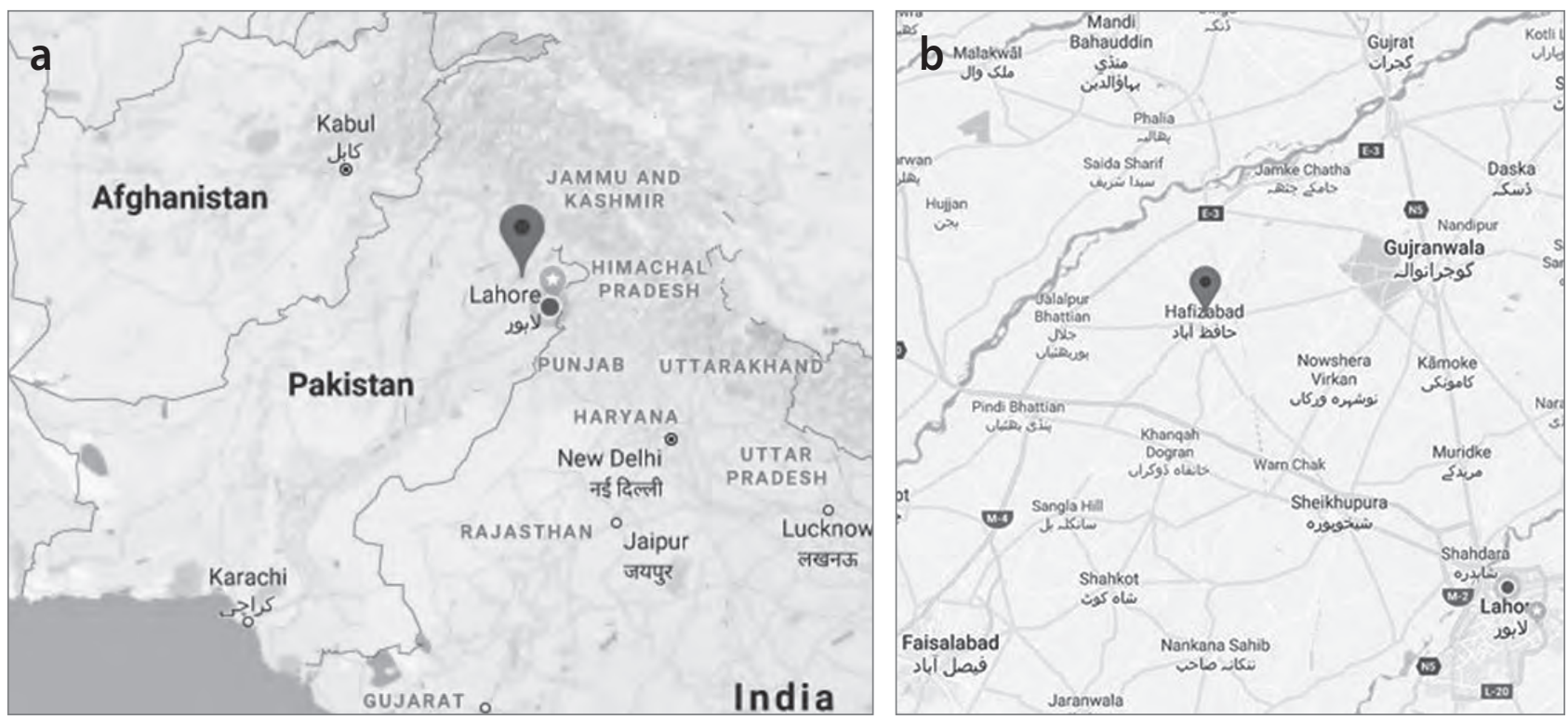

Figure 1: a) Location of Hafizabad in Pakistan (source: Google Maps, 2019); b) Location of Hafizabad in the regional context (source: Google Maps, 2019).
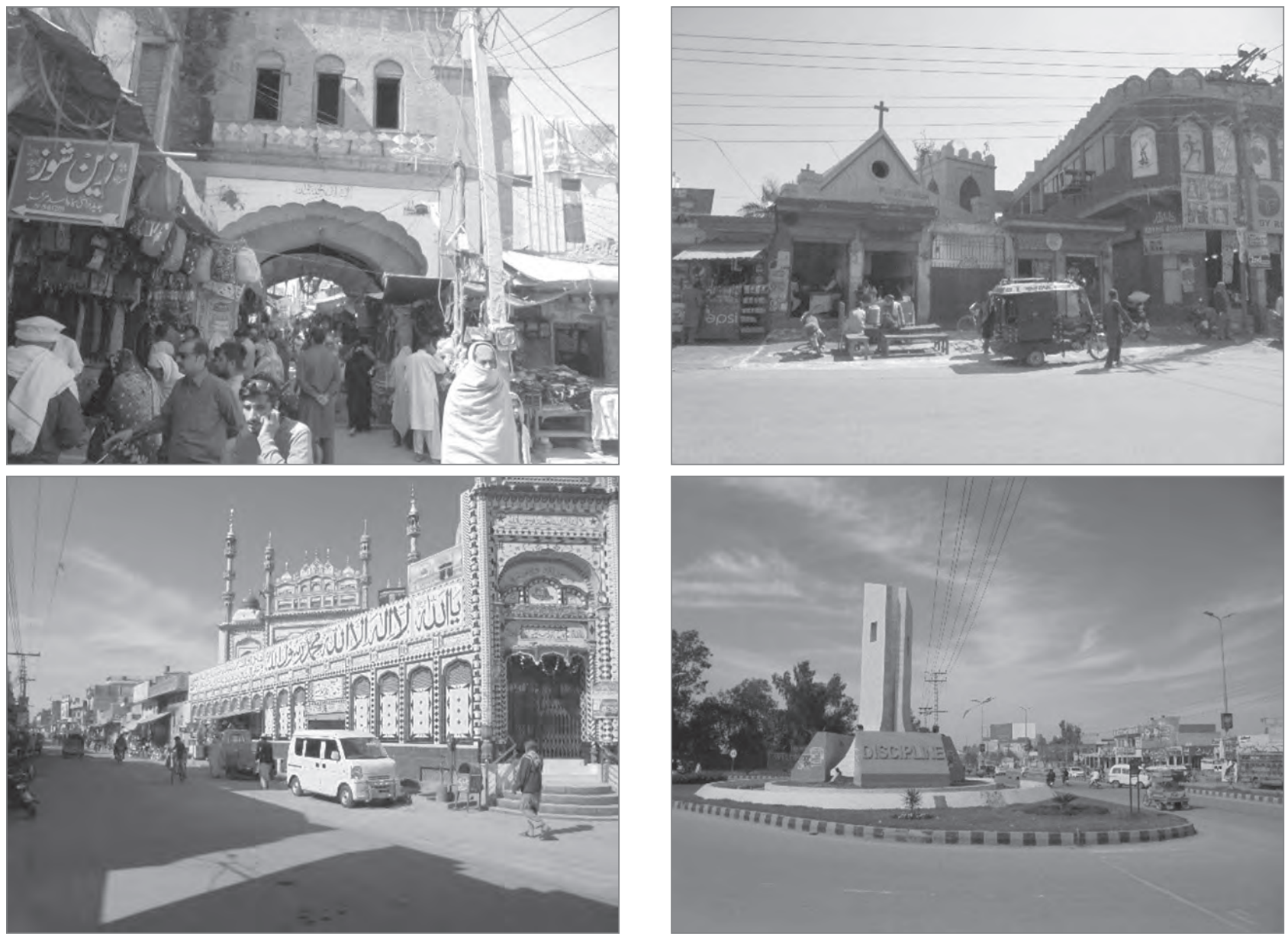

Figure 2: Various urban layers of Hafizabad (photo: Anwaar ul Haq). 
Table 2: The four case-study neighbourhoods selected.

\begin{tabular}{lllllllll}
\hline No. & Neighbourhood & Period & Grid type & $\begin{array}{l}\text { Population } \\
(2018)\end{array}$ & $\begin{array}{l}\text { Gross } \\
\text { area (ha) }\end{array}$ & Net area (ha) & $\begin{array}{l}\text { Gross population } \\
\text { density (per ha) }\end{array}$ & $\begin{array}{l}\text { Net population } \\
\text { density (per ha) }\end{array}$ \\
\hline 1 & Gali Haji Miraj Deen & pre 1947 & Organic & 3,584 & 5.5 & 4.9 & 649.11 & 730.54 \\
\hline 2 & Sharifpura & pre 1947 & Organic & 3,298 & 31.5 & 27.4 & 104.64 & 120.26 \\
\hline 3 & Nawab Colony & $1947-2000$ & Semi-grid & 4,299 & 8.9 & 6.8 & 484.88 & 636.74 \\
\hline 4 & Hassan Town & post 2000 & Full-grid & 7,861 & 22.7 & 20.1 & 346.73 & 514.64 \\
\hline
\end{tabular}

Table 3: Urban characteristics of the selected case-study neighbourhoods.

\begin{tabular}{|c|c|c|c|c|c|c|c|c|c|c|}
\hline \multirow[t]{2}{*}{ No. } & \multirow[t]{2}{*}{ Neighbourhood } & \multirow[t]{2}{*}{ Links } & \multirow[t]{2}{*}{ Nodes } & \multirow[t]{2}{*}{ Link-node ratio } & \multirow{2}{*}{$\begin{array}{l}\text { Intersection } \\
\text { density (nodes/ha) }\end{array}$} & \multicolumn{4}{|c|}{ Facilities } & \multirow{2}{*}{$\begin{array}{l}\text { Per capita } \\
\text { facilities }\end{array}$} \\
\hline & & & & & & 言 & 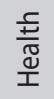 & 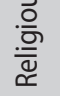 & $\begin{array}{l}\overline{\sqrt{0}} \\
\stackrel{0}{\circ}\end{array}$ & \\
\hline 1 & Gali Haji Miraj Deen & 66 & 59 & 1.12 & 10.73 & 43 & 1 & - & 44 & 0.012 \\
\hline 2 & Sharifpura & 190 & 168 & 1.13 & 5.33 & 119 & - & - & 119 & 0.036 \\
\hline 3 & Nawab Colony & 44 & 35 & 1.26 & 3.93 & 66 & - & 1 & 67 & 0.016 \\
\hline 4 & Hassan Town & 83 & 45 & 1.84 & 1.98 & 72 & - & 1 & 73 & 0.009 \\
\hline
\end{tabular}

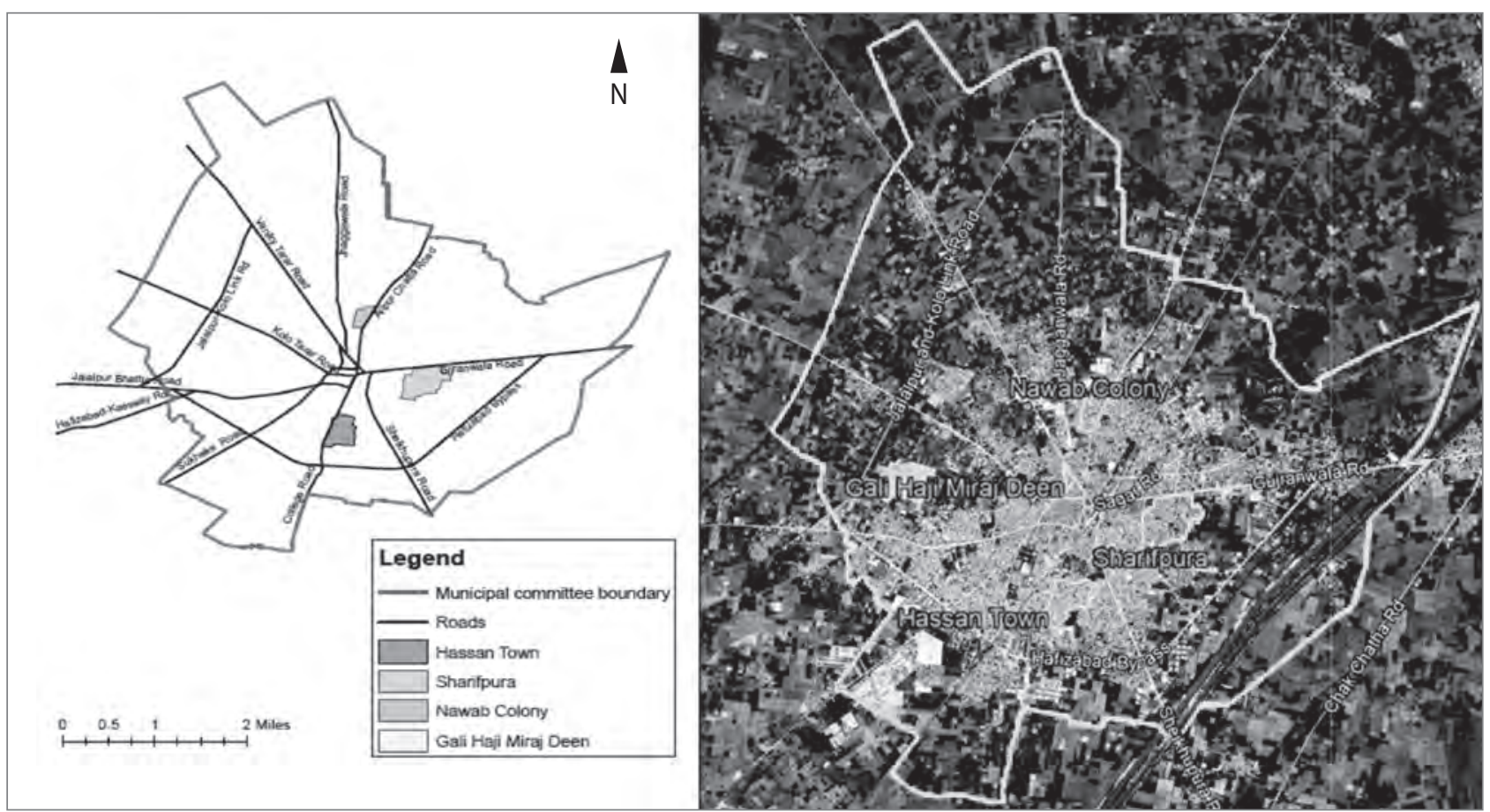

Figure 3: Location of the neighbourhoods studied in Hafizabad (illustration: authors).

the entire Indian subcontinent operated under British colonial rule until 1947. During that period, British rule made an indelible impression on the region's urban fabric through Victorian architecture. The same is the case with Hafizabad, where vestiges of the colonial urban layer can be seen in the central parts of the city. This urban layer is part of the pre-partition (i.e., pre-1947) built environment of Hafizabad. After Pakistan's independence in 1947, much of the Hindu and Sikh population of the city migrated to India, and, in turn, many Muslims from India settled in Hafizabad. This demographic transition helped transform the urban landscape of the city, thus giving rise to an urban layer of the post-partition period (from independence until the late 1990s). Pakistan's 2001 National Housing Policy declared housing a priority sector, resulting in a real estate boom. Small cities like Hafizabad were no exception. They also faced the consequences of urban sprawl in the form of housing developments outside of municipal borders, although it was less intense than in larger cities. This gave birth to the third urban layer: newer planned developments and gated communities. The various urban layers of Hafizabad are shown in Figure 2. 


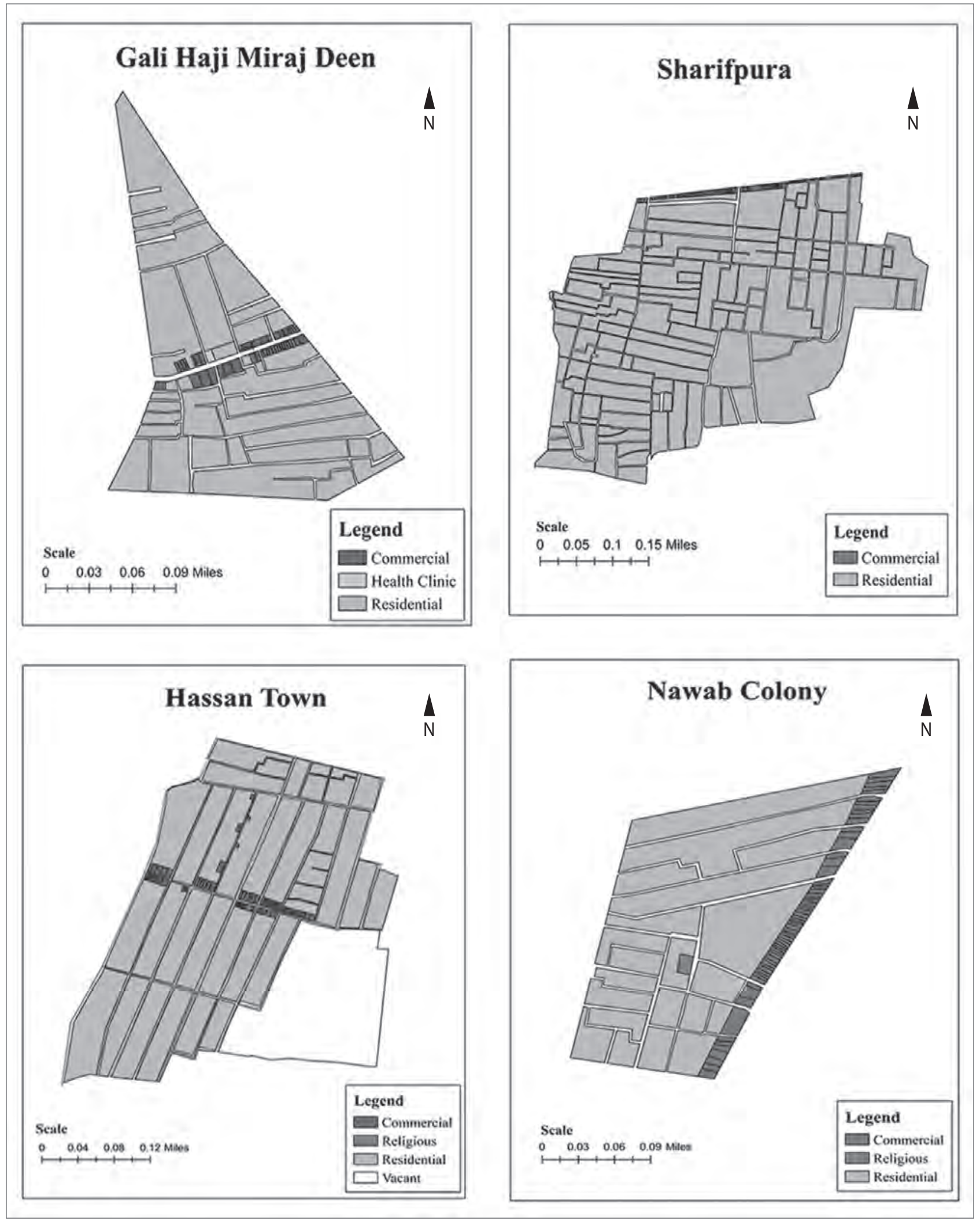

Figure 4: Land-use functions of the selected case-study neighbourhoods (illustration: authors). 
Identifying various urban layers helped in selecting case-study neighbourhoods based on differences in the built environment. Differences in the urban character also reflect some differences in the socioeconomic status of their residents. The city mainly grew to the south to accommodate newer developments, including planned housing schemes. Four neighbourhoods in Hafizabad were selected for detailed investigation based on the main criterion of a distinct urban form. Two of them belong to older central parts of the city, one in the northern part having a semi-grid form, and one chosen from the new developments in the southern part of the city. The urban characteristics and details of the facilities available in these four neighbourhoods are provided in Tables 2 and 3, and their location within the city is shown in Figure 3. The urban form and available facilities in each neighbourhood are shown in Figure 4.

\subsection{Data, variables, and analysis}

The survey was divided into three parts: household and socioeconomic information, current dwelling unit characteristics, and housing demand characteristics. It included sixteen questions, some of which consisted of more than one question or conditional questions. The questionnaire contained six individual questions (age, sex, marital status, employment, commuting time, and commuting mode), and ten household questions covering vehicle ownership, type of housing, reason for choosing the place, date of moving, main reason for moving, owning another housing unit, number of owned housing units, vacant/occupied housing, tenure type, unit price, unit rent, search for new housing, neighbourhood preference, main reason for choosing where to live, and preferred tenure type. Except for the number of housing units owned, all of the variables are categorical. The questionnaires were completed by the interviewers while talking to the respondents.

The survey provides exploratory data for the case-study neighbourhoods with a high level of precision. The sample sizes and the estimated confidence intervals were based on Cochran's (1963) formulation. These figures were calculated separately for individual and household questions. The household confidence intervals were calculated using the average household size of the city (6.6, based on the 2017 census result). As a result, $1.9 \%$ of the 19,042 residents in the overall population $(N)$ were interviewed. Regarding household questions, the survey collected data for about $12.7 \%$ of the city's households. This provides a confidence interval of $\pm 5.1 \%$ for individual questions and $\pm 4.8 \%$ for household questions. The confidence intervals for neighbourhoods are given in Table 4, which summarizes the sample size for each question, based on the general sample of 365 respondents.
The analysis included frequency reports related to categorical variables and descriptive statistics reports related to the number of housing units owned (the only continuous variable). This was done after validating and correcting the results, which was primarily done for the Nawab Colony data, which contained some problematic input that was removed from the sample.

\section{Results}

A summary of the collective findings regarding categorical indicators for the overall sample of the four neighbourhoods is presented below. Among the respondents, $45 \%$ were thirty-six to forty-five years old, with $84 \%$ male. Balancing the number of male and female respondents proved to be difficult due to cultural considerations. Similar to the high share of middle-aged respondents, $82 \%$ of the survey participants were married and $78 \%$ were employed full-time.

Consistent with several other surveys conducted in neighbouring countries and nearby regions, household vehicle ownership was targeted instead of individual ownership. In such cultures, it is more likely that household members use vehicles together. In this vein, $56 \%$ of the households owned one motorbike, $22 \%$ had no car, and only $5 \%$ had one car. A large percentage of the responding households (87\%) owned self-built houses, whereas only $12 \%$ lived in rented housing. As expected for the case of a small Pakistani city, $41 \%$ of the households (such as young couples or similar) lived in their family's houses. Living on family property was the most important reason for choosing the current place of living. Living in a family property is followed by two weaker reasons: $16 \%$ of the households chose their current house because it was located in a nice neighbourhood, and $14 \%$ found the current house affordable. A large share of the respondents (73\%) reached their place of work or education in less than thirty minutes. Walking and riding a motorbike are the dominant commuting mode, each making up $40 \%$ of the responses. More than one-third of the responding households had moved at the time of the survey. This share of the sample is the focus of this article for studying motives for moving and self-selections. The most frequently cited time of the last move was between two and ten years ago (42\%). The living unit type or neighbourhood was the most important reason for $15 \%$ of the respondents, considering that $65 \% \mathrm{did}$ not answer this question because they had not moved before. Transportation was a motive for moving for almost none of the households surveyed $(0.27 \%)$. Only $18 \%$ of the households in the sample owned a second living unit, about half of which were occupied. 
Table 4: Neighbourhood-level sample characteristics and overall sample.

\begin{tabular}{|c|c|c|c|c|c|c|c|c|c|}
\hline $\begin{array}{l}\text { ठ } \\
\circ \\
\frac{1}{1} \\
\overline{0} \\
\frac{0}{5} \\
\frac{.0}{2} \\
\frac{1}{2}\end{array}$ & 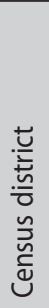 & 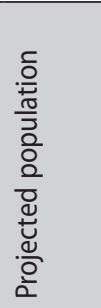 & 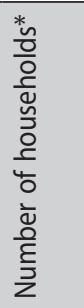 & 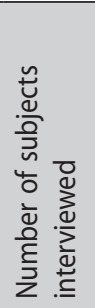 & 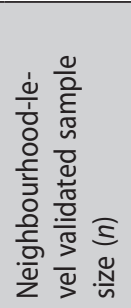 & 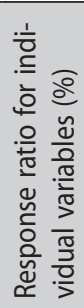 & 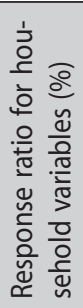 & 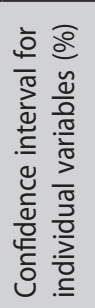 & 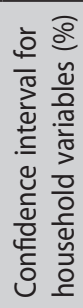 \\
\hline Hassan Town & 12 & 7,861 & 1,191 & 100 & 100 & 1.27 & 8.40 & 9.74 & 9.38 \\
\hline Sharifpura & 10 & 3,298 & 500 & 100 & 100 & 3.03 & 20.00 & 9.65 & 8.77 \\
\hline Gali HajiMiraj Deen & 6 & 3,584 & 543 & 100 & 100 & 2.79 & 18.42 & 9.66 & 8.86 \\
\hline Nawab Colony & 5 & 4,299 & 651 & 98 & 65 & 1.51 & 9.98 & 12.06 & 11.54 \\
\hline Total sample & - & 19,042 & 2,885 & 398 & 365 & 1.92 & 12.65 & 5.08 & 4.79 \\
\hline
\end{tabular}

Note: *Calculated by the average household size of Hafizabad (6.6).

Only $11 \%$ of the sample rented a living unit, and all the others lived in their own house. More than half of these houses cost between PKR 1.5 and 3 million. Of the $11 \%$ that rented a house, $68 \%$ paid less than one-third of their income for rent. In the future, $28 \%$ intend to search for a new house. About half of the sample is interested in continuing to live in their current neighbourhood in the future, whereas $45 \%$ will look for housing in another neighbourhood in Hafizabad and the remaining 5\% are interested in leaving Hafizabad and living in another city, most likely Lahore. Having good services and utilities (neighbourhood amenities) is the most important reason for moving for $23 \%$ of respondents, followed by a reasonable price for $20 \%$. Transportation (proximity to work) is a reason for $17 \%$ of the households. Finally, $91 \%$ would prefer to move into their own house in the future.

The above information is related to the overall sample of respondents from all four neighbourhoods. To understand the role of different urban forms and environments on respondents' choices in each of the four neighbourhoods, the outputs of the categorical variables were analysed separately for each case site and also presented in graphs. Selected graphs are presented in Figure 6. Hassan Town had the youngest respondents (44\%), whereas Gali Haji Miraj Deen and Sharifpura were older, with $25 \%$ of the respondents aged forty-six or older. Women had the largest share in Hassan Town (32\%), and the smallest share of unmarried respondents came from Nawab Colony (28\%). Gali Haji Miraj Deen had the largest share of full-time employees (84\%), the largest share of people with one motorbike (62\%), and the highest car ownership rate. Self-built houses are found equally frequently in Gali Haji Miraj Deen, Sharifpura, and Hassan Town (86-88\%), and the highest share of house-renters came from Gali Haji Miraj Deen (10\%). However, living on family property is the dominant form of housing in the overall sample. Affordability, proximity to work, and living in a nice neighbourhood are the most important reasons for respondents living in their cur- rent house. The sociocultural status of this subset is slightly different from the entire sample. Hassan Town had the shortest commuting distances, with $79 \%$ of respondents reporting that their trips take less than half an hour. This figure falls to $67 \%$ for Nawab Colony. Nawab Colony also has the lowest walking mode (28\%). Half of the households in Hassan Town have already moved, compared to $27 \%$ in Sharifpura. More than half of the responding households in Nawab Colony moved within the past two years, whereas 40\% in Gali Haji Miraj Deen moved over ten years ago. Transportation reasons were important for only $1.5 \%$ in Nawab Colony and were not a reason for moving in the other areas surveyed. Possession of another living unit is seen most often in Nawab Colony (28\%). At 88 to $90 \%$, house ownership is almost equal in the four neighbourhoods. According to the self-reported findings concerning house prices in this survey, the cheapest houses are found in Hassan Town (29\%), whereas the most expensive houses are in Nawab Colony (16\%). In Hassan Town, $91 \%$ of respondents spend less than one-third of their income on rent. The highest share of households surveyed intending to move is in Sharifpura (32\%). For the overall sample, 41 to $54 \%$ of responding households intend to remain in their neighbourhood in the future. Respondents in Hassan Town showed the least interest in moving out of the neighbourhood (37\%). For respondents interested in moving to another city, Lahore is more likely to be selected compared to more distant cities. In Gali Haji Miraj Deen, the most important reason for deciding where to live in the future is the availability of services and utilities (31\%). In Sharifpura, the main motives are affordability (22\%), followed by availability of services and utilities (21\%), and proximity to social relations and relatives (20\%). Affordability (30\%) and proximity to work (29\%) are by far the most influential reasons in Hassan Town. Finally, respondents in Nawab Colony look for services and utilities (29\%) and a quiet environment (23\%) more than other issues. Between 85 and $99 \%$ of the respondents of the four neighbourhoods would like to own a house when they move in the future. 


\begin{tabular}{|c|c|c|c|c|c|c|}
\hline \multirow[t]{2}{*}{ Average house area } & \multicolumn{2}{|l|}{ Valid } & \multicolumn{2}{|l|}{ Missing } & \multicolumn{2}{|l|}{ Total } \\
\hline & $N$ & Percent & $N$ & Percent & $N$ & Percent \\
\hline & 350 & $95.9 \%$ & 15 & $4.1 \%$ & 365 & $100.0 \%$ \\
\hline \multicolumn{7}{|l|}{ Descriptives } \\
\hline \multirow{2}{*}{ Mean } & & Statistic & 122.33 & \multirow{2}{*}{ Std. deviation } & Statistic & 50.183 \\
\hline & & Std. Error & 2.682 & & Std. error & - \\
\hline \multirow{2}{*}{$\begin{array}{l}95 \% \text { confidence interval } \\
\text { for mean }\end{array}$} & Lower Bound & Statistic & 117.06 & \multirow{2}{*}{ Minimum } & Statistic & 20 \\
\hline & Upper Bound & & 127.61 & & Std. error & - \\
\hline \multirow{2}{*}{$5 \%$ trimmed mean } & & Statistic & 118.49 & \multirow{2}{*}{ Maximum } & Statistic & 379 \\
\hline & & Std. Error & - & & Std. error & - \\
\hline \multirow{2}{*}{ Median } & & Statistic & 126.00 & \multirow{2}{*}{ Range } & Statistic & 359 \\
\hline & & Std. Error & - & & Std. error & - \\
\hline \multirow{2}{*}{ Variance } & & Statistic & 2518.302 & \multirow{2}{*}{ - Interquartile range } & Statistic & 37 \\
\hline & & Std. Error & - & & Std. error & - \\
\hline \multirow{2}{*}{ Kurtosis } & & Statistic & 3.989 & \multirow{2}{*}{ Skewness } & Statistic & 1.428 \\
\hline & & Std. Error & 0.260 & & Std. error & 0.130 \\
\hline \multicolumn{7}{|l|}{ Tests of normality } \\
\hline \multirow[t]{3}{*}{ Category } & \multicolumn{2}{|c|}{ Kolmogorov-Smirnov } & & \multicolumn{2}{|l|}{ Shapiro-Wilk } & \\
\hline & Statistic & df & $p$-value & Statistic & df & $p$-value \\
\hline & 0.242 & 350 & $<0.001$ & 0.875 & 350 & $<0.001$ \\
\hline
\end{tabular}

Figure 5: Descriptive statistics and normality test for the area of the respondents' housing (source: authors).

The survey included only one continuous variable: the area of housing owned by each household. The descriptive statistics related to this question are presented in Figure 5. Out of 365 respondents, 350 answered this question. The areas range from $20 \mathrm{~m}^{2}$ to $379 \mathrm{~m}^{2}$, with a mean of $122.3 \mathrm{~m}^{2}$ and a standard error of only $2.68 \mathrm{~m}^{2}$. The large range of $359 \mathrm{~m}^{2}$ is due to some outliers at the upper end of the range. The results of the Kolmogorov-Smirnov and Shapiro-Wilk tests of normality yielded $p$-values of less than 0.001 , indicating non-normality.

\section{Discussion}

Like many previous studies on this topic, this study employed quantitative methods to generate findings on the residential location choices of Hafizabad residents. In line with previous studies, the neighbourhood was selected as the unit of analysis. The sampling frame for conducting this study was the census data for the neighbourhoods. Similar to the majority of previous studies on the same topic, the methodological consideration of selecting four neighbourhoods in Hafizabad was based on differences in urban character and different periods they belong to. Because the literature review indicated a low response rate for indirect data collection methods (i.e., self-administered mailed surveys), direct interviewing through field surveys was selected as the data collection method. The response ratio of $1.92 \%$ for this study is within the range reported by past studies conducted in the developed world. The discussion presented shows that the chosen methodology is in line with many previous studies on similar topics in developed country contexts. This indicates the reliability of the findings of this study.

The findings reveal that, for the majority of the respondents that own their self-built houses and have lived there for more than two years, their main reason for choosing their current housing location is the family's property. The high homeownership rate in Pakistan stands in sharp contrast with the situation in the developed world. An increased ratio of home ownership reduces overall housing mobility; consequently, the majority of respondents consider their family's property to be the main deciding criterion for determining where to live. Owning houses reflects socioeconomic status within $\mathrm{Pa}$ kistani society, which does not provide much motivation to rent housing units. The joint family system as a dominant living style of many of the households in developing countries may also foster the importance of family property as the leading criterion for residential location choice. These findings are not in line with the results of studies conducted in the developed world.

Proximity to the workplace did not turn out to be one of the leading reasons for current residential location of the respondents. This could be a reflection of the small size of the city, where most jobs are not as distant from homes as is sometimes the case in larger cities. Around three-fourths of the respond- 


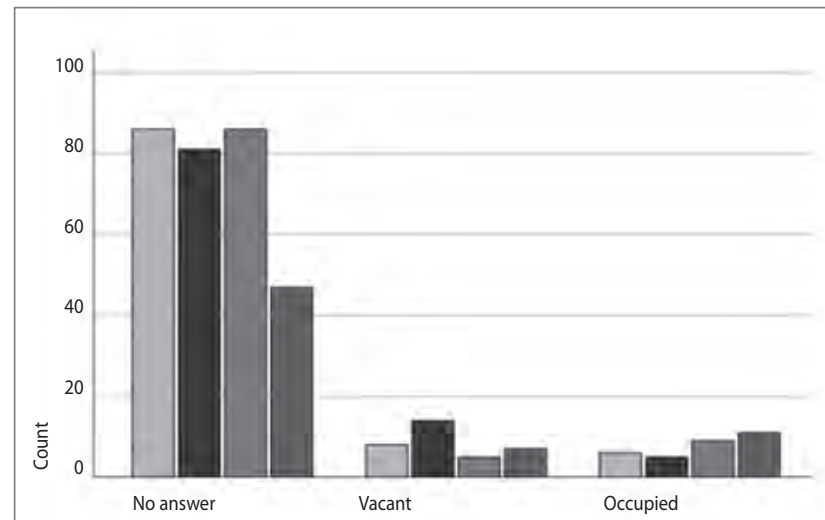

Present status of housing units

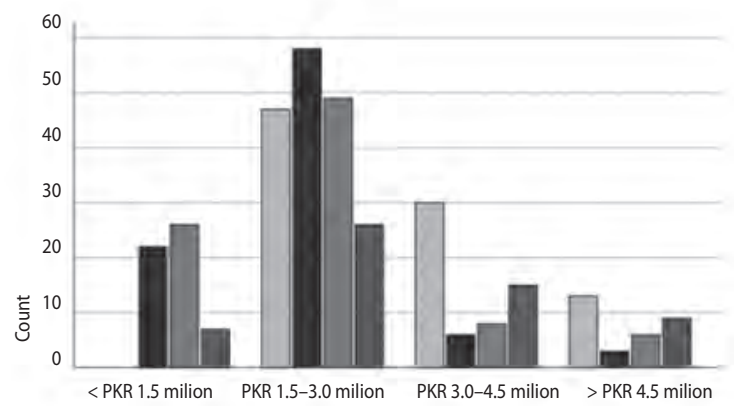

Actual price of house on real estate market

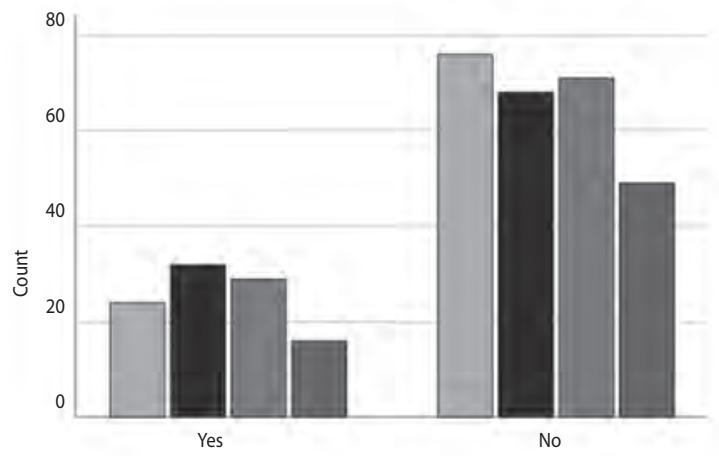

In search of new house?

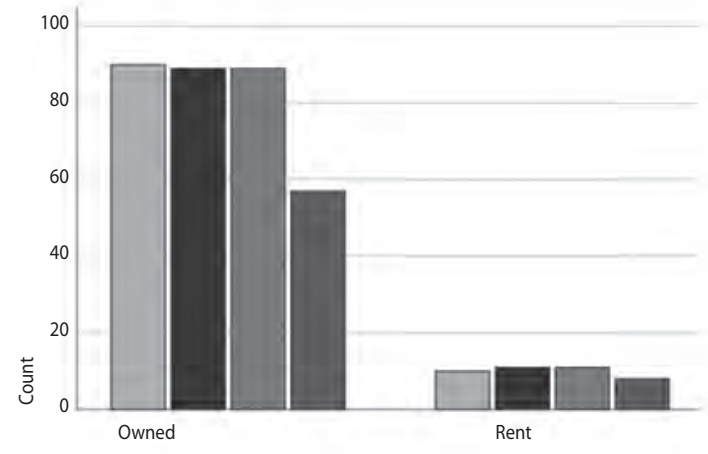

Type of housing tenure

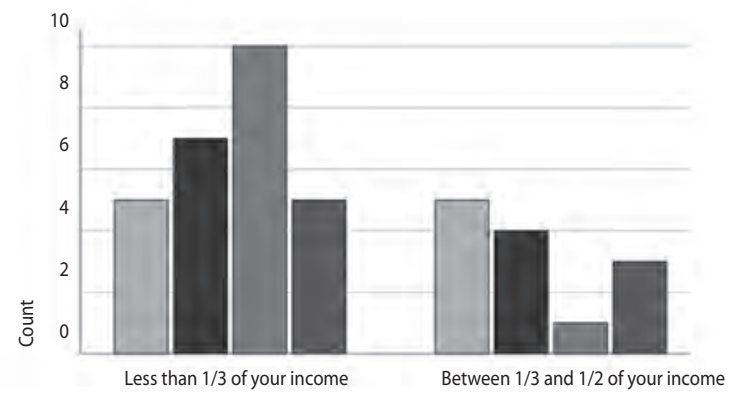

If renting, you pay:

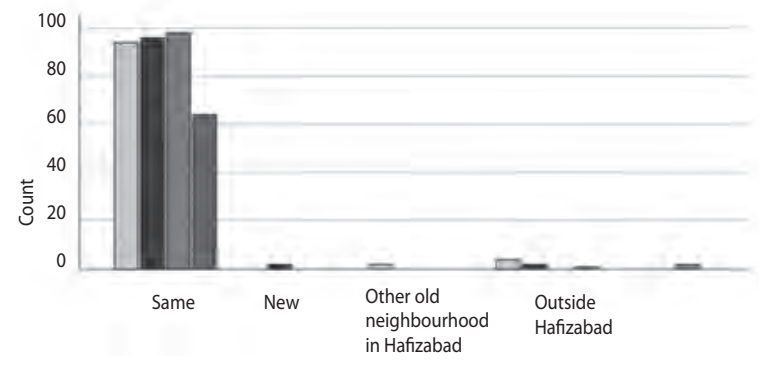

Preferred neighbourhood

Figure 6: Selected graphs presenting the frequencies of responses for variables analysed for case-study neighbourhoods (source: authors).

ents require less than thirty minutes to reach their jobs, and the preferred mode of travel for around $40 \%$ of respondents is walking. This shows a good job-housing balance and could be representative of other smaller cities in Pakistan, which generally grew organically with fewer planning controls. This also provides a clue for why proximity to work is not among the leading factors for residential location choice in a small city. This is further strengthened by the finding that transportation was not a motivating factor for any of the households that had moved in the past. Again, such findings contrast with findings from studies conducted in the developed world. In another study by the authors (forthcoming) in a large urban centre of Lahore, the average commuting distance to work for a residential neighbourhood was found to be $8.4 \mathrm{~km}$; investigating the factors for residential location choices in that sample might yield different results. The insignificance of transportation or proximity to work in influencing residential location choice in smaller cities suggests that a massive push toward transit-oriented development might not be a wise strategy for smaller cities in the developing world. 
Another important insight from this study is the intent of out-migration. Although the share of current residents intending to move out of the city is only $5 \%$, the tendency of out-migrating to larger cities (especially Lahore) is a notable finding. Although the reasons for such intentions are unknown, relevant municipal government departments should try to devise policies to help curb the urbanization of larger cities in Pakistan. The city of Lahore is already saturated in terms of size and population, and the continuous addition of population through in-migration from surrounding small cities will aggravate the situation by further overburdening the existing infrastructure.

The main limitation of this study is that only around one-third of the respondents moved in the past and were thus able to provide the main deciding factor behind deciding where to live. This was due to the high homeownership rate in Pakistan. For all other respondents, the questions inquired about their intentions to move in the near future and their anticipated deciding factors for deciding where to live. However, only onefourth of the respondents reported that they were searching for a new home. Furthermore, because the responses to such questions related to an uncertain future time, they might vary at the time of actual moving. This shortcoming of the collected data was addressed by asking respondents about their current intentions to move, and therefore this limitation will not have any significant impact on the reliability of the findings.

\section{Conclusion}

The methodology of this study was carefully designed in line with the methodological considerations of many previous studies conducted in the developed world. Due to the high home-ownership rate in Pakistan, a family's current housing was the leading deciding factor when deciding where to live. Access to transportation facilities or proximity to jobs were not leading factors in deciding where to live. This could be a manifestation of the small size of Hafizabad, where the study was conducted. It also reflects the fact that small Pakistani cities are more compact, are denser, and have a good job-housing balance compared to large cities. These findings allow relevant policy-oriented circles to better devise urban and transportation policies to achieve the objectives of transit-oriented development, address low-income housing issues, and manage the urbanization of large cities. This study shows that transportation factors are insignificant in deciding where to live in a small city with a population of 245,784 (2017). However, the situation in large urban centres could be different and should be investigated more thoroughly. Similar studies on the large urban centres of Pakistan are needed to understand the situation more clearly. Furthermore, this study presents survey results in a descriptive form only, and further empirical studies are needed to ascertain the relationship of different variables and corroborate this study's findings. It is suggested that similar studies be replicated in other smaller cities of the developing world with a particular focus on the younger population, especially young couples or families, because their decisions will significantly shape the future course of urban commuting patterns.

Atif Bilal Aslam, Department of City and Regional Planning, University of Engineering and Technology Lahore, Pakistan E-mail: atif.aslam@uet.edu.pk

Houshmand E. Masoumi, Centre for Technology and Society, Technical University of Berlin, Germany

E-mail: masoumi@ztg.tu-berlin.de

Nida Naeem, Department of City and Regional Planning, University of Engineering and Technology Lahore, Pakistan

E-mail: nida.naeem64@yahoo.com

Mohammad Ahmad, Department of City and Regional Planning, University of Engineering and Technology Lahore, Pakistan E-mail: ahmadnoul786@gmail.com

\section{References}

Ahmad, N. (1992) Choice of location and mobility behaviour of migrant households in a third world city. Urban Studies, 29(7), pp. 1147-1157. DOI: 10.1080/00420989220081091

Ahmad, N. (1993) Choice of neighbourhoods by mover households in Karachi. Urban Studies, 30(7), pp. 1257-1270. DOI: 10.1080/00420989320081161

Ahmad, N. \& Anjum, G. A. (2012) Legal and institutional perplexities hampering the implementation of urban development plans in Pakistan. Cities, 29(4), pp. 271-277. DOI: 10.1016/j.cities.2011.07.006

Balbontin, C., Ortúzar, J. de D. \& Swait, J. D. (2015) A joint best-worst scaling and stated choice model considering observed and unobserved heterogeneity: An application to residential location choice. Journal of Choice Modelling, 16, pp. 1-14. DOI: 10.1016/j.jocm.2015.09.002

Bayoh, I., Irwin, E. G. \& Haab, T. (2006) Determinants of residential location choice: How important are local public goods in attracting homeowners to central city locations? Journal of Regional Science, 46(1), pp. 97-120. DOI: 10.1111/j.0022-4146.2006.00434.x

Biying, Y., Zhang, J. \& Fujiwara, A. (2012) Analysis of the residential location choice and household energy consumption behavior by incorporating multiple self-selection effects. Energy Policy, 46, pp. 319-334. DOI: 10.1016/j.enpol.2012.03.067

Buczkowska, S. \& Lapparent, M. de (2014) Location choices of newly created establishments: Spatial patterns at the aggregate level. Regional Science and Urban Economics, 48, pp. 68-81. DOI: 10.1016/j.regsciurbeco.2014.05.001

Cao, X., Handy, S. L. \& Mokhtarian, P. L. (2006a) The influences of the built environment and residential self-selection on pedestrian behavior: Evidence from Austin, TX. Transportation, 33(1), pp. 1-20. DOI: $10.1007 / \mathrm{s} 11116-005-7027-2$ 
Cao, X., Mokhtarian, P. L. \& Handy, S. L. (2006b) Neighborhood design and vehicle type choice: Evidence from northern California. Transportation Research Part D: Transport and Environment, 11(2), pp. 133-145. DOI: 10.1016/j.trd.2005.10.001

Cao, X., Mokhtarian, P. L. \& Handy, S. L. (2009) Examining the impacts of residential selflselection on travel behaviour: A focus on empirical findings. Transport Reviews, 29(3), pp. 359-395. DOI: 10.1080/01441640802539195

Cao, X., Xu, Z. \& Fan, Y. (2010) Exploring the connections among residential location, self-selection, and driving: Propensity score matching with multiple treatments. Transportation Research Part A: Policy and Practice, 44(10), pp. 797-805. DOI: 10.1016/j.tra.2010.07.010

Chiarazzo, V., Coppola, P., Dell'Olio, L., Ibeas, A. \& Ottomanelli, M. (2014) The effects of environmental quality on residential choice location. Procedia - Social and Behavioral Sciences, 162, pp. 178-187. DOI: 10.1016/j.sbspro.2014.12.198

Choocharukul, K., Van, H. T. \& Fujii, S. (2008) Psychological effects of travel behavior on preference of residential location choice. Transportation Research Part A: Policy and Practice, 42(1), pp. 116-124. DOI: 10.1016/j.tra.2007.06.008

Choudhury, C. F. \& Ayaz, S. B. (2015) Why live far? - Insights from modeling residential location choice in Bangladesh. Journal of Transport Geography, 48, pp. 1-9. DOI: 10.1016/j.jtrangeo.2015.08.001

Cochran, W. G. (1963) Sampling techniques. New York, John Wiley and Sons.

Connor, K. M. (1989) Factors in the residential choices of self-settled Afghan refugees in Peshawar, Pakistan. International Migration Review, 23(4), pp. 904-932. DOI: 10.1177/019791838902300408

Ettema, D. \& Nieuwenhuis, R. (2017) Residential self-selection and travel behaviour: What are the effects of attitudes, reasons for location choice and the built environment? Journal of Transport Geography, 59, pp. 146-155. DOI: 10.1016/j.jtrangeo.2017.01.009

Fatmi, M. R., Chowdhury, S. \& Habib, M. A. (2017) Life history-oriented residential location choice model: A stress-based two-tier panel modeling approach. Transportation Research Part A: Policy and Practice, 104, pp. 293-307. DOI: 10.1016/j.tra.2017.06.006

Frank, L. D., Saelens, B. E., Powell, K. E. \& Chapman, J. E. (2007) Stepping towards causation: Do built environments or neighborhood and travel preferences explain physical activity, driving, and obesity? Social Science \& Medicine, 65(9), pp. 1898-1914.

DOI: 10.1016/j.socscimed.2007.05.053

Frenkel, A., Bendit, E. \& Kaplan, S. (2013) Residential location choice of knowledge-workers: The role of amenities, workplace and lifestyle. Cities, 35, pp. 33-41. DOI: 10.1016/j.cities.2013.06.005

Ge, J. \& Hokao, K. (2006) Research on residential lifestyles in Japanese cities from the viewpoints of residential preference, residential choice and residential satisfaction. Landscape and Urban Planning, 78(3), pp. 165-178. DOI: 10.1016/j.landurbplan.2005.07.004

Google (2019) Map of study area. Available at: https://bit.ly/2XIZbyt (accessed 17 Feb. 2019)

Government of Pakistan (2017) 6th Population and Housing Census - 2017. Islamabad.

Government of the Punjab (2018) Punjab portal. Available at: https:// www.punjab.gov.pk/hafizabad_history (accessed 25 Jun. 2018).

Hameed, R. \& Nadeem, O. (2008) Challenges of implementing urban master plans: The Lahore experience. International Journal of Humanities and Social Sciences, 2(12), pp. 1297-1304.
Handy, S. L. \& Clifton, K. J. (2001) Local shopping as a strategy for reducing automobile travel. Transportation, 28(4), pp. 317-346.

Heldt, B., Gade, K. \& Heinrichs, D. (2016) Determination of attributes reflecting household preferences in location choice models. Transportation Research Procedia, 19, pp. 119-134. DOI: 10.1016/j.trpro.2016.12.073

Humphreys, J. \& Ahern, A. (2017) Is travel based residential self-selection a significant influence in modal choice and household location decisions? Transport Policy, 75, pp. 150-160.

DOI: 10.1016/j.tranpol.2017.04.002

Ibrahim, M. R. (2017) How do people select their residential locations in Egypt? The case of Alexandria. Cities, 62, pp. 96-106. DOI: 10.1016/j.cities.2016.12.012

Jun, M.-J., Ha, S.-K. \& Jeong, J.-E. (2013) Spatial concentrations of Korean Chinese and determinants of their residential location choices in Seoul. Habitat International, 40, pp. 42-50. DOI: 10.1016/j.habitatint.2013.02.002

Kim, J. H., Pagliara, F. \& Preston, J. (2005) The intention to move and residential location choice behaviour. Urban Studies, 42(9), pp. 16211636. DOI: $10.1080 / 00420980500185611$

Kitamura, R., Mokhtarian, P. L. \& Laidet, L. (1997) A micro-analysis of land use and travel in five neighborhoods in the San Francisco Bay area. Transportation, 24(2), pp. 125-158.

Lall, S. V., Suri, A. \& Deichmann, U. (2006) Household savings and residential mobility in informal settlements in Bhopal, India. Urban Studies, 43(7), pp. 1025-1039. DOI: 10.1080/00420980500406744

Masoumi, H. E. (2013) Residential self-selection and its effects on urban commute travels in Iranian cities compared to US, UK, and Germany. International Journal of Social Sciences, 7(5), pp. 877-881.

Molugaram, K. \& Rao, K. V. (2005) A stated preference residential location choice model in Indian context (= Australasian Transport Research Forum (ATRF) 28). Sydney, Curtin University.

Naeem, N. \& Ahmad, M. (2018) Residential location choice behaviour: A case study of city Hafizabad-Punjab. Lahore, University of Engineering and Technology.

Næss, P. (2009) Residential self-selection and appropriate control variables in land use: Travel studies. Transport Reviews, 29(3), pp. 293-324. DOI: 10.1080/01441640802710812

Næss, P. (2013) Residential location, transport rationales and daily-life travel behavior: The case of Hangzhou Metropolitan Area, China. Progress in Planning, 79, pp. 1-50. DOI: 10.1016/j.progress.2012.05.001

Painter, K. (1996) The influence of street lighting improvements on crime, fear and pedestrian street use, after dark. Landscape and Urban Planning, 35(2-3), pp. 193-201. DOI: 10.1016/0169-2046(96)00311-8

Palma, A. de, Motamedi, K., Picard, N. \& Waddell, P. (2005) A model of residential location choice with endogenous housing prices and traffic for the Paris region. European Transport, 31, pp. 67-82.

Park, J. \& Kim, K. (2016) The residential location choice of the elderly in Korea: A multilevel logit model. Journal of Rural Studies, 44, pp. $261-$ 271. DOI: 10.1016/j.jrurstud.2016.02.009

Patacchini, E. \& Arduini, T. (2016) Residential choices of young Americans. Journal of Housing Economics, 34, pp. 69-81.

DOI: 10.1016/j.jhe.2016.08.003

Pinjari, A. R., Pendyala, R. M., Bhat, C. R. \& Waddell, P. A. (2011) Modeling the choice continuum: An integrated model of residential location, auto ownership, bicycle ownership, and commute tour mode choice decisions. Transportation, 38(6), p. 933. DOI: 10.1007/s11116-011-9360-y 
Schwanen, T. \& Mokhtarian, P. L. (2004) The extent and determinants of dissonance between actual and preferred residential neighborhood type. Environment and Planning B: Planning and Design, 31(5), pp. 759784. DOI: $10.1068 / \mathrm{b} 3039$

Schwanen, T. \& Mokhtarian, P., L. (eds.) (2003) Does dissonance between desired and current residential neighbourhood type affect individual travel behaviour? An empirical assessment from the San Francisco Bay area. Earlier faculty research. Berkeley, CA, UC Berkeley. Available at: https:// escholarship.org/uc/item/26k8w6xf (accessed 13 Mar. 2019).

Sener, I. N., Pendyala, R. M. \& Bhat, C. R. (2011) Accommodating spatial correlation across choice alternatives in discrete choice models: an application to modeling residential location choice behavior. Journal of Transport Geography, 19(2), pp. 294-303.

DOI: 10.1016/j.jtrangeo.2010.03.013

Srinivasan, S. (2005) Influence of residential location on travel behavior of women in Chennai, India. In: National Research Council (ed.) Research on women's issues in transportation, report of a conference. Volume 2, technical papers, pp. 4-13. Washington, DC: TRB.

Tran, M. T., Zhang, J., Chikaraishi, M. \& Fujiwara, A. (2016) A joint analysis of residential location, work location and commuting mode choices in Hanoi, Vietnam. Journal of Transport Geography, 54, pp. 181-193. DOI: 10.1016/j.jtrangeo.2016.06.003

Van Acker, V., Mokhtarian, P. L. \& Witlox, F. (2014) Car availability explained by the structural relationships between lifestyles, residential location, and underlying residential and travel attitudes. Transport Policy, 35, pp. 88-99. DOI: 10.1016/j.tranpol.2014.05.006

Van der Vlist, Arno J, Gorter, C., Nijkamp, P. \& Rietveld, P. (2002) Residential mobility and local housing-market differences. Environment and Planning A, 34(7), pp. 1147-1164. DOI: 10.1068/a34176

Vega, A. \& Reynolds-Feighan, A. (2009) A methodological framework for the study of residential location and travel-to-work mode choice under central and suburban employment destination patterns. Transportation Research Part A: Policy and Practice, 43(4), pp. 401-419.

DOI: 10.1016/j.tra.2008.11.011

Vos, J. de \& Witlox, F. (2016) Do people live in urban neighbourhoods because they do not like to travel? Analysing an alternative residential self-selection hypothesis. Travel Behaviour and Society, 4, pp. 29-39. DOI: 10.1016/j.tbs.2015.12.002

Waddell, P., Bhat, C., Eluru, N., Wang, L. \& Pendyala, R. M. (2007) Modeling interdependence in household residence and workplace choices. Transportation Research Record: Journal of the Transportation Research Board, 2003(1), pp. 84-92. DOI: 10.3141/2003-11

Wang, L., Waddell, P. \& Outwater, M. L. (2011) Incremental integration of land use and activity-based travel modeling, Transportation Research Record: Journal of the Transportation Research Board, 2255(1), pp. 1-10. DOI: $10.3141 / 2255-01$

Wang, M., Yang, Y., Jin, S., Gu, L. \& Zhang, H. (2016) Social and cultural factors that influence residential location choice of urban senior citizens in China - The case of Chengdu city. Habitat International, 53, pp. 55-65. DOI: 10.1016/j.habitatint.2015.10.011

Wang, Y., Peng, Z. \& Chen, Q. (2018) The choice of residential layout in urban China: A comparison of transportation and land use in Changsha (China) and Leeds (UK). Habitat International, 75, pp. 50-58. DOI: 10.1016/j.habitatint.2018.04.005

Wu, W., Zhang, W. \& Dong, G. (2013) Determinant of residential location choice in a transitional housing market: Evidence based on micro survey from Beijing. Habitat International, 39, pp. 16-24.

DOI: 10.1016/j.habitatint.2012.10.008
Yang, L., Zheng, G. \& Zhu, X. (2013) Cross-nested logit model for the joint choice of residential location, travel mode, and departure time. Habitat International, 38, pp. 157-166. DOI: 10.1016/j.habitatint.2012.06.002

Yi, C. \& Lee, S. (2014) An empirical analysis of the characteristics of residential location choice in the rapidly changing Korean housing market. Cities, 39, pp. 156-163. DOl: 10.1016/j.cities.2014.03.002

Yu, B., Zhang, J. \& Li, X. (2017) Dynamic life course analysis on residential location choice. Transportation Research Part A: Policy and Practice, 104, pp. 281-292. DOI: 10.1016/j.tra.2017.01.009

Zhang, J., Yu, B. \& Chikaraishi, M. (2014) Interdependences between household residential and car ownership behavior: A life history analysis. Journal of Transport Geography, 34, pp. 165-174.

DOI: 10.1016/j.jtrangeo.2013.12.008

Zhuge, C., Shao, C., Gao, J., Dong, C. \& Zhang, H. (2016) Agent-based joint model of residential location choice and real estate price for land use and transport model. Computers, Environment and Urban Systems, 57, pp. 93-105. DOI: 10.1016/j.compenvurbsys.2016.02.001

Zondag, B. \& Pieters, M. (2005) Influence of accessibility on residential location choice. Transportation Research Record: Journal of the Transportation Research Board, 1902, pp. 63-70. DOI: 10.3141/1902-08 